DOI: $10.24850 /$ j-tyca-2019-04-11

Special Article

\title{
Impact of Water Allocation on Soil Desalination and Groundwater Hydro-chemical Characteristics: A Temporal and Spatial Analysis of a Case Study Region in China \\ Impacto de agua distribuida en tierra desalinizada y características hidroquímicas de aguas subterráneas: análisis temporal y espacial de un estudio de caso regional en China
}
P. $\mathrm{Li}^{1 *}$
N. Magzum ${ }^{2}$
X. $\mathrm{Qi}^{3 *}$
Y. Zhang ${ }^{4}$
Z. $\mathrm{Du}^{5}$
Z. Liang ${ }^{6}$
Z. Huang ${ }^{7}$

${ }^{1}$ Chinese Academy of Agricultural Sciences, Farmland Irrigation Research Institute, Xinxiang, China, email: firilp@163.com, ORCID 0000-0001-8322-2327

${ }^{2}$ Chinese Academy of Agricultural Sciences, Agriculture Water and Soil Environmental Field Science Research Station of Xinxiang City, Xinxiang, China, email: Ipaska7979@sina.com, ORCID 0000-0002-6454-6323

${ }^{3}$ Chinese Academy of Agricultural Sciences, Farmland Irrigation Research Institute, Xinxiang, China, email: qxb6301@sina.cn, ORCID 0000-0002-4931-3089

${ }^{4}$ Chinese Academy of Agricultural Sciences, Key laboratory of high-efficient and safe utilization of agriculture water resources, Xinxiang, China, email: 15136479128@163.com, ORCID 0000-0002-8797-7708

${ }^{5}$ Chinese Academy of Agricultural Sciences, Agriculture Water and Soil Environmental Field Science Research Station of Xinxiang City, Xinxiang, China, email: imdzj11@163.com, ORCID 0000-0002-0510-9537

${ }^{6}$ Chinese Academy of Agricultural Sciences, Agriculture Water and Soil Environmental Field Science Research Station of Xinxiang City, Xinxiang, China, email: liang_zhj@163.com, ORCID 0000-0001-6373-9804 
${ }^{7}$ Chinese Academy of Agricultural Sciences, Key laboratory of high-efficient and safe utilization of agriculture water resources, Xinxiang, China, email: zdhuang@126.com, ORCID 0000-0002-1639-4820

*Corresponding author: Ping Li, firilp@163.com and Xuebin Qi, qxb6301@sina.cn

\section{Novelty Statement}

The negative effect of water allocation has been rarely evaluated for improving water resources use efficiency in canal well combined irrigation district. The results showed that more surface water irrigation could drive salinity leaching to the lower soil horizons while average TDS concentration of groundwater has been increased by $18.66 \%$ in the study area. We found that combined well canal irrigation could be of water allocation method due mainly to temporal and spatial regulation water resources and root layer soil desalination, however, the possible increasing of TDS in the groundwater may cause potential risk after long term implementing water allocation in a semi-arid area

\section{Abstract}

The influence of water resources allocation patterns on root layers soil desalination and groundwater quality were investigated by monitoring different irrigation area from People's Victory Canal irrigation district in Huang Huai Hai plain China that had been conducted well canal combined irrigation patterns from 1954. A typical area was chosen belong to the People's Victory Canal irrigation district from 2013 to 2015. Precipitation of the area, surface water irrigation amount, groundwater consumption amount, salinity content in 0 to $100 \mathrm{~cm}$ soil layer and total dissolved solids in groundwater were monitored, the ratio of canal-well water (the ratio of surface water to groundwater irrigation amount, CWWR), soil salinity spatial dynamic, desalinization rate in 0 to $100 \mathrm{~cm}$ soil layer and sodium adsorption ratio (SAR) of groundwater were analyzed in the area. CWWR of Branch 1, Branch 2, and Branch 3 ranged from 0.72 to 1.03, 2.50 to 2.63 , and 0.65 to 1.26 in 2013 to 2015 , respectively. The soil salinity contents for the top $100 \mathrm{~cm}$ horizons in the Branch 2 irrigation area decreased slightly by $1.63 \%$ to $8.90 \%$ compared with the values in the Branch 1 and Branch 3 irrigation districts while the water resources allocation patterns were conducted two years later. Compared with the area in the hydrological period in 2013, the area of average soil salinity exceeded $0.32 \mathrm{mS} / \mathrm{cm}$ for the top $20 \mathrm{~cm}$ horizons has decreased notably in 2014 and 2015. Compared with the values in 2014, the average TDS concentration of groundwater increased by $18.66 \%$ in the study 
area in 2015, whereas the sodium adsorption ratio (SAR) values in the above-mentioned irrigation areas decreased by $23.58 \%, 36.82 \%$, and $53.37 \%$ in the normal period in 2015. The combined well-canal irrigation pattern could represent a useful water allocation method mainly because of the temporal and spatial regulation of water resources and root layer soil desalination; however, possible increases of TDS in the groundwater may cause potential ecosystem degradation risks after long-term water allocation in semi-arid areas. Thus, water allocation should be emphasized to maintain a healthy groundwater environment and sustainable stable yields of grain in combined canal-well irrigation districts.

Keywords: Combined well canal irrigation, Water allocation, Soil salinity, Desalinization rate, Hydro-chemical characteristics, Sodium adsorption ratio.

Received

Accepted

\section{Introduction}

Excessive soil salinity can inhibit or restrain crop growth, irrigation results in the accumulation of salt to above-normal concentrations in the rooting zone of arable land because high rates of evaporation and transpiration draw soluble salts from deeper layers of the soil profile in arid and semiarid climatic zones (Rozema et al. 2008). According to the National Agricultural Sustainable Development Planning (2015-2030), Huang Huai Hai plain is one of the important agricultural optimization development areas in China, although its environmental resource-carrying capacity does not meet the planning requirements (Yang et al. 2016). Water resources allocation technology was initiated in Huang Huai Hai plain starting in the 1950 s in China, and it included the comprehensive management of the groundwater depth and crop growth to increase crop yields (Shi et al. 2013). The early water and salt balance estimation results of the plain showed that $25.7 \%$ of the water consumption entered the sea, and the majority of water consumption occurred via evaporation and transpiration. For example, $0.04 \%$ to $0.4 \%$ salinity levels were found in the precipitation and Yellow river water, respectively, and they may enrich the soil salinity by 0.04 billion tons per year (Wei. 1995), which corresponds to 0.16 million tons per year of salinity accumulating in the soil horizon in the People's Victory Canal irrigation district. In recent years, the ratio of agricultural water to water consumption in the Huang 
Huai Hai Plain has declined each year regardless of the advantages of various practices to promote the safe use of limited water resources for agriculture (Yang et al. 2016, Yang et al. 2013). As a result of the decreased agricultural water consumption, the gap of agricultural water demand in the Huang Huai Hai plain exceeded 10 billion $\mathrm{m}^{3}$ (Yang et al. 2015), and many questions have been raised with regard to changes in groundwater depth and accumulation of salt in soil profiles, which may consequently degrade the soil quality and crop yield. For instance, the sliding average precipitation value of 3 years was reduced by 2.92 $\mathrm{mm}$ /an according to a regression analysis, and the agricultural water consumption in the past 5 years was nearly $75 \%$ of the annual average value of agricultural water consumption in the People's Victory Canal irrigation district (Li et al. 2017), however, the topsoil salinity was elevated (Han et al. 2016, Mora et al. 2017).

Most studies on agricultural water management have focused on developing optimal algorithms for allocation models and determining the water availability and water resource carrying capacity in arid and semi-arid irrigation areas (Wang et al. 2016, Fulazzaky et al. 2014, Bekchanov et al. 2010, Sadati et al. 2014, Wu et al. 2014, Parna et al. 2014, Esmaeili et al. 2015, Al-Omari A et al. 2009), where excessive groundwater exploitation would lead to a sharp drop in groundwater level and raise the groundwater salinity (Mo et al. 2016), and inappropriate water management would improve root layer soil salinity and soil secondary salinization (Singh et al. 2012). Additionally, decreases in precipitation in arid and semi-arid areas have led to excessive groundwater exploitation and basin closure (Molden et al. 2007, Molle et al. 2010).

This study was conducted to estimate the effect of water allocation on soil profiles salinity, groundwater depth and groundwater hydro-chemical characteristics in western $3^{\text {rd }}$ main canal area using location monitoring methodology. Although researchers mentioned above tried to determined water allocation patterns in well canal combined irrigation district, the highlight of the paper over the other in that in our methodology, we imposed soil profiles desalination and groundwater hydro-chemical characteristics, and the suitable water allocation pattern was put forward for well canal combined irrigation district.

\section{The Study Area}

General Description. The western $3^{\text {rd }}$ main canal irrigation area lies in the center of the People's Victory canal irrigation district, the area of which is about $800 \mathrm{hm}^{2}$, the average annual precipitation is about $580 \mathrm{~mm}$ with about $70 \%$ of 
the precipitation occurring from June to September, while the average annual water surface evaporation is about $1860 \mathrm{~mm}$, with most of the irrigation events occurring in January, March, May and June. The western $3^{\text {rd }}$ main canal irrigation area, shown in Figure 1 includes three branch canals. The research area is a typical intensive combined well-canal irrigation area in the People's Victory Canal irrigation district, which is characterized by an equipped foundation and a complete system of distribution canals, and three branch canals belong to the $3^{\text {rd }}$ western main canal. The irrigation areas of the Branch 1, Branch 2, and Branch 3 are $300,213.3$ and $286.7 \mathrm{hm}^{2}$, respectively. Additionally, approximate indexes of cropping rotational system, water use habits and irrigation technology in the research area are available for the research area, and the irrigation schedule employed is the traditional border irrigation schedule that occurs in winter, the green stage of winter wheat, and the summer maize seeding stage with surface water and groundwater in the normal hydrological year, 1200 to $1800 \mathrm{~m}^{3} / \mathrm{hm}^{2}$ irrigation amount applied per time. The water allocation practices of branch canals operations are shown in Table 1 . The total dissolved solids content of surface water and groundwater employed is 390 to 452,762 to $1464 \mathrm{mg} / \mathrm{L}$, respectively.

$$
\mathrm{CWWR}=\frac{S W I M}{G W I M}
$$

where CWWR represents the canal-well water ratio, which is the ratio of SWIM to GWIM, SWIM represents the surface water irrigation amount, and GWIM represents the groundwater irrigation amount.

Table 1. Irrigation amounts from surface water and groundwater for the branch canal areas in 2013-2015.

\begin{tabular}{|c|c|c|c|c|c|c|c|c|c|}
\hline \multirow{2}{*}{ Year } & \multicolumn{3}{|c|}{ Branch 1 } & \multicolumn{3}{c|}{ Branch 2 } & \multicolumn{3}{c|}{ Branch 3 } \\
\cline { 2 - 11 } & $\begin{array}{c}\text { SWIM } \\
\left(\times \mathbf{1 0}^{\mathbf{4}} \mathbf{~ m}^{\mathbf{3}}\right)\end{array}$ & $\begin{array}{c}\text { GWIM } \\
\left(\times \mathbf{1 0}^{\mathbf{4}} \mathbf{~ m}^{\mathbf{3}}\right)\end{array}$ & CWWR & $\begin{array}{c}\text { SWIM } \\
\left(\times \mathbf{1 0}^{\mathbf{4}} \mathbf{~ m}^{\mathbf{3}}\right)\end{array}$ & $\begin{array}{c}\text { GWIM } \\
\left(\times \mathbf{1 0}^{\mathbf{4}} \mathbf{~ m}^{\mathbf{3}}\right)\end{array}$ & CWWR & $\begin{array}{c}\text { SWIM } \\
\left(\times \mathbf{1 0}^{\mathbf{4}} \mathbf{~ m}^{\mathbf{3}}\right)\end{array}$ & $\begin{array}{c}\text { GWIM } \\
\left(\times \mathbf{1 0}^{\mathbf{4}} \mathbf{~ m}^{\mathbf{3}}\right)\end{array}$ & CWWR \\
\hline 2013 & 207.87 & 201.67 & 1.03 & 208.44 & 79.11 & 2.63 & 213.69 & 169.01 & 1.26 \\
\hline 2014 & 140.11 & 161.33 & 0.87 & 158.06 & 63.29 & 2.50 & 129.83 & 135.21 & 0.96 \\
\hline 2015 & 128.08 & 177.00 & 0.72 & 181.13 & 70.40 & 2.57 & 121.33 & 186.33 & 0.65 \\
\hline
\end{tabular}




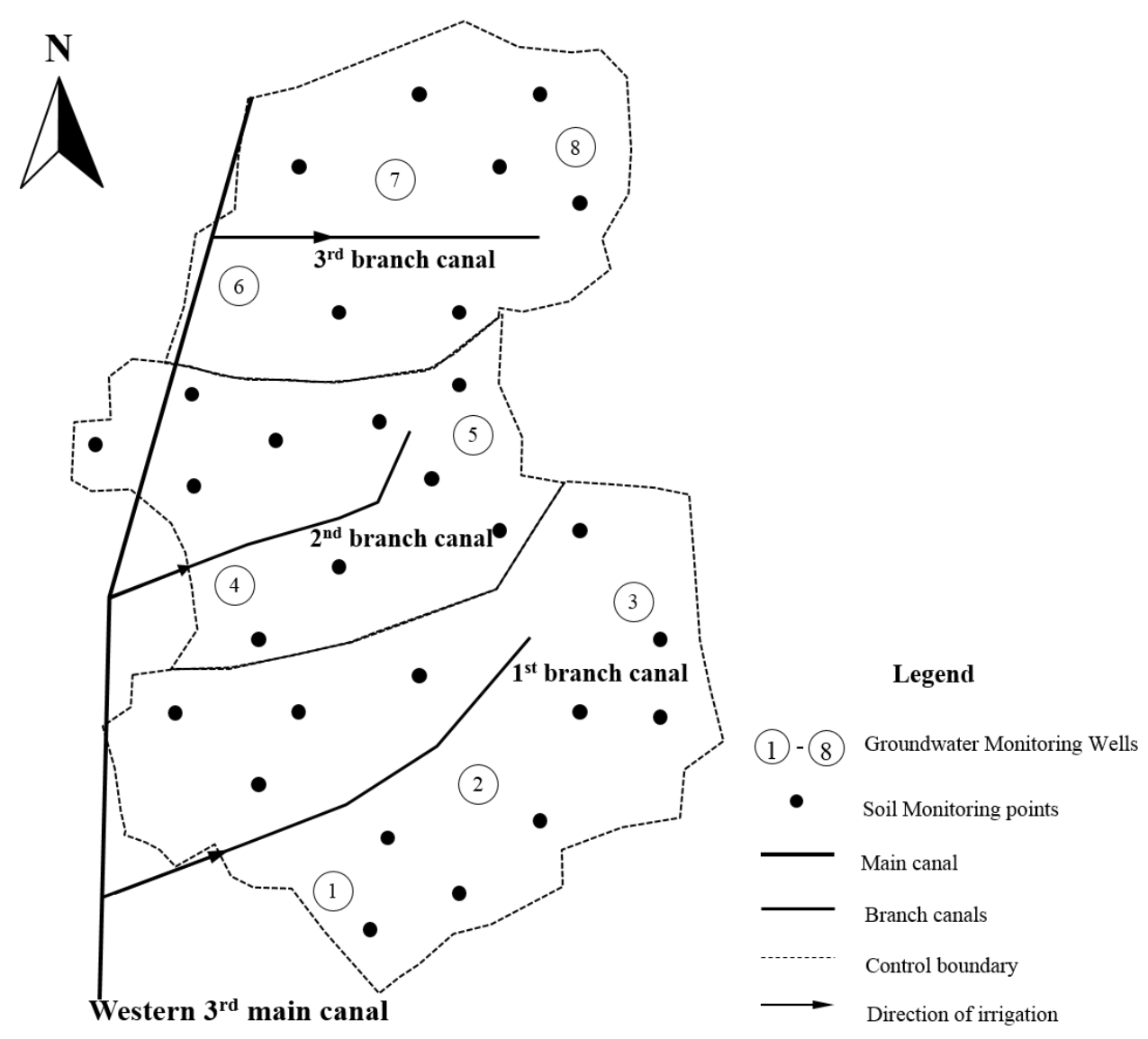

Figure 1. The layout of western $3^{\text {rd }}$ main canal in the People's Victory Canal irrigation district.

Soil Sampling. Soils were sampled at fixed locations at winter wheat seeding stage (approximate $15^{\text {th }}$ Oct. per year). Soil samples were collected at depth of 0 to $10 \mathrm{~cm}, 10$ to $20 \mathrm{~cm}, 20$ to $30 \mathrm{~cm}, 30$ to $40 \mathrm{~cm}, 40$ to $60 \mathrm{~cm}, 60$ to $80 \mathrm{~cm}$ and 80 to $100 \mathrm{~cm}$ with a standard $3.5 \mathrm{~cm} \varnothing$ soil auger, 5 samples were collected per plot and stored at room temperature before analyzing for electrical conductivity (EC). The EC was measured in extracts of soil pastes (1:5 soil to water ratio). Soil samples locations are shown in Figure 1.

Groundwater Monitoring. Groundwater sampled at $20^{\text {th }}$ per month, depth-setting sampler (Solinst 425, Solinst, Canada) was employed below $20 \mathrm{~cm}$ of groundwater depth (phreatic aquifer). The $\mathrm{pH}$ was measured in $\mathrm{pH}$ meter method (PHSJ-5, Leici, Shanghai). The EC was measured in conductivity meter method (DDSJ-308A, Leici, Shanghai). $\mathrm{K}^{+}, \mathrm{Na}^{+}, \mathrm{Ca}^{2+}, \mathrm{Mg}^{2+}$ concentration in the groundwater was determined using atomic absorption method (AA-7000, SHIMADZU, Japan), $\mathrm{CO}_{3}{ }^{2-}, \mathrm{HCO}_{3}{ }^{-}, \mathrm{SO}_{4}{ }^{2-}, \mathrm{Cl}^{-}$concentration in the groundwater 
was determined using ion chromatography method (ICS-1500, Dionex, USA). Groundwater samples locations are shown in Figure 1.

Soil Desalination Rate Calculation.

$$
D R=\frac{N^{t h} S S-(N+1)^{t h} S S}{N^{t h} S S} \times 100 \%
$$

where $D R$ represents the soil desalination rate (\%) [22], $N^{\text {th }} S S$ represents the soil horizons salinity in winter wheat seeding stage of $N^{\text {th }}$ year, $(N+1)^{\text {th }} S S$ represents the soil horizons salinity in winter wheat seeding stage of $(N+1)^{\text {th }}$ year, $N$ represents the number of the natural years.

\section{Results and Discussion}

\section{Characteristic of Precipitation and Irrigation Implementation}

Characteristic of precipitation and irrigation implementation was shown in Figure 2. The average annual precipitation is about $574 \mathrm{~mm}$ in the study area, while the yearly precipitation in 2013, 2014 and 2015 was 466.9, 558.5 and $569.6 \mathrm{~mm}$, respectively. Additionally, precipitation occurred in major flood period accounted for $67.08 \%, 73.36 \%$ and $51.74 \%$ in 2013, 2014 and 2015, respectively. According to seasonal period, precipitation occurred in spring season was 135.0 $\mathrm{mm}$, increased by $20.11 \%$ compared with the average annual seasonal precipitation, while precipitation occurred in summer, autumn and winter season was 306.2, 111.0, $17.4 \mathrm{~mm}$, respectively, increased by $-10.57 \%, 10.89 \%,-8.90 \%$ compared with the average annual seasonal precipitation in 2015 , respectively. 


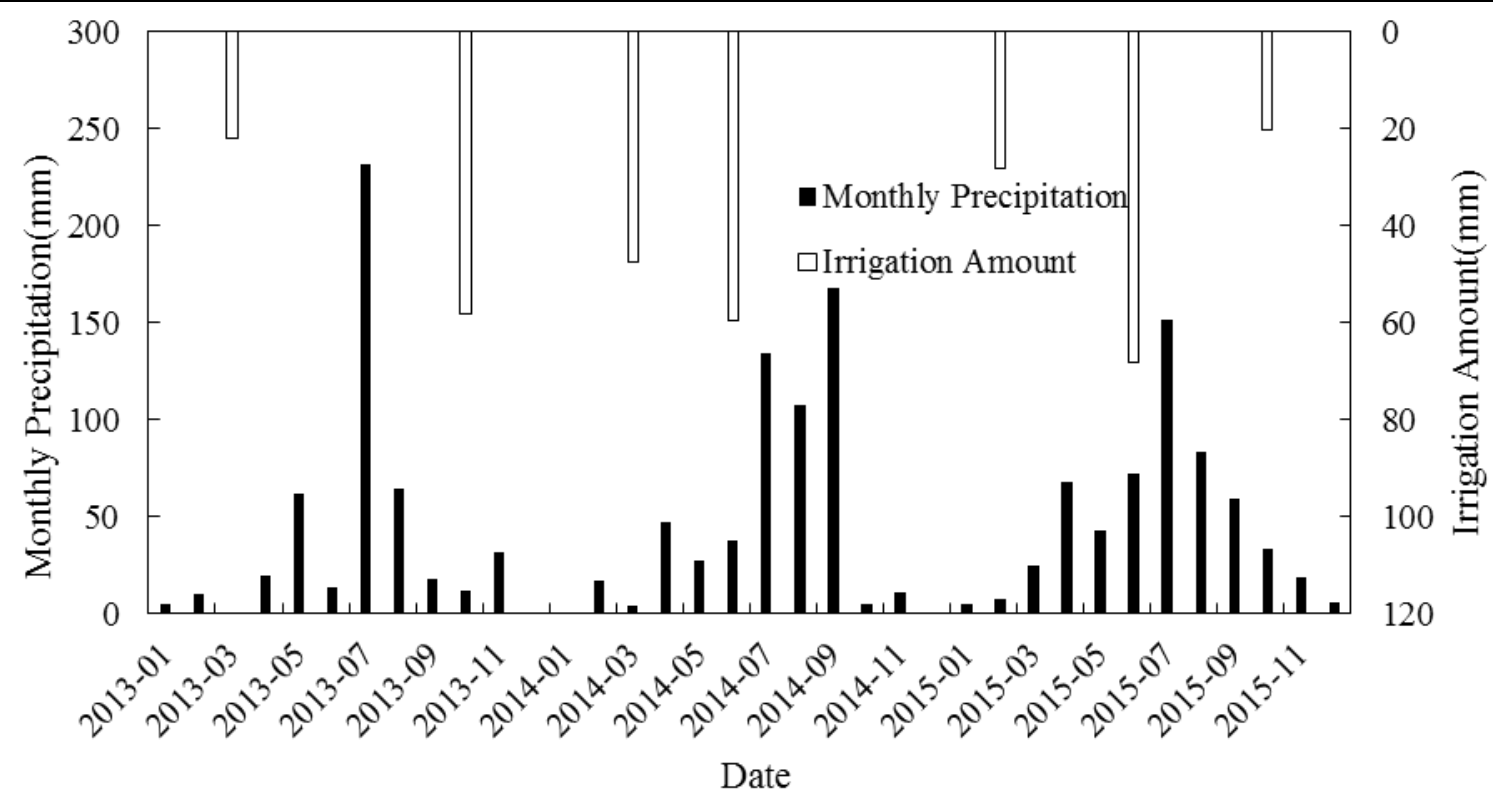

Figure 2. Distribution of monthly precipitation and irrigation amounts from 2013 to 2015.

Irrigation was employed in the seeding stage and green up stage of winter wheat in 2013 , irrigation amount was $22.2,58.2 \mathrm{~mm}$, respectively. While irrigation was employed in green up stage of winter wheat and seeding stage of summer maize in 2014, irrigation amount was 47.6, $59.8 \mathrm{~mm}$, respectively. And irrigation was employed in green up stage of winter wheat, seeding stage of winter wheat and summer maize in 2015, irrigation amount was 28.3, 68.2, $20.3 \mathrm{~mm}$, respectively.

\section{Dynamic of Root Layer Salinity}

The dynamics of soil layer salinity by date in the study area are shown in Figure 3. It may be observed that soil salinity accumulated in the soil profile $(0-10 \mathrm{~cm})$ in the seeding stage of winter wheat in 2013-2015, varied from 0.2839 to 0.4129 $\mathrm{mS} / \mathrm{cm}$. The dynamic of soil salinity in examined soil profiles had similar distribution trends in soil horizons in 2013 to 2015, with the salinity of the top 10 $\mathrm{cm}$ layer in the irrigation area presenting higher values compared with the content in other soil profiles. At a lower depth of $30 \mathrm{~cm}$, lower salinity was found in the soil profiles from 2013 to 2015. Compared with the values in the same period in 2013, the average soil salinity in the seeding stage decreased by 9.04 to $26.18 \%, 9.78$ to $33.28 \%$, and 4.56 to $36.35 \%$ in the soil profiles $(0-100 \mathrm{~cm})$ in 
the irrigation area of the Branch 1, Branch 2, and Branch 3, respectively, in 2014, whereas the average soil salinity in 2015 was reduced by 1.05 to $31.26 \%, 8.34$ to $27.18 \%$, and 9.72 to $18.06 \%$ in the soil profiles $(0-100 \mathrm{~cm})$ in the irrigation area of the Branch 1, Branch 2 and Branch 3, respectively.

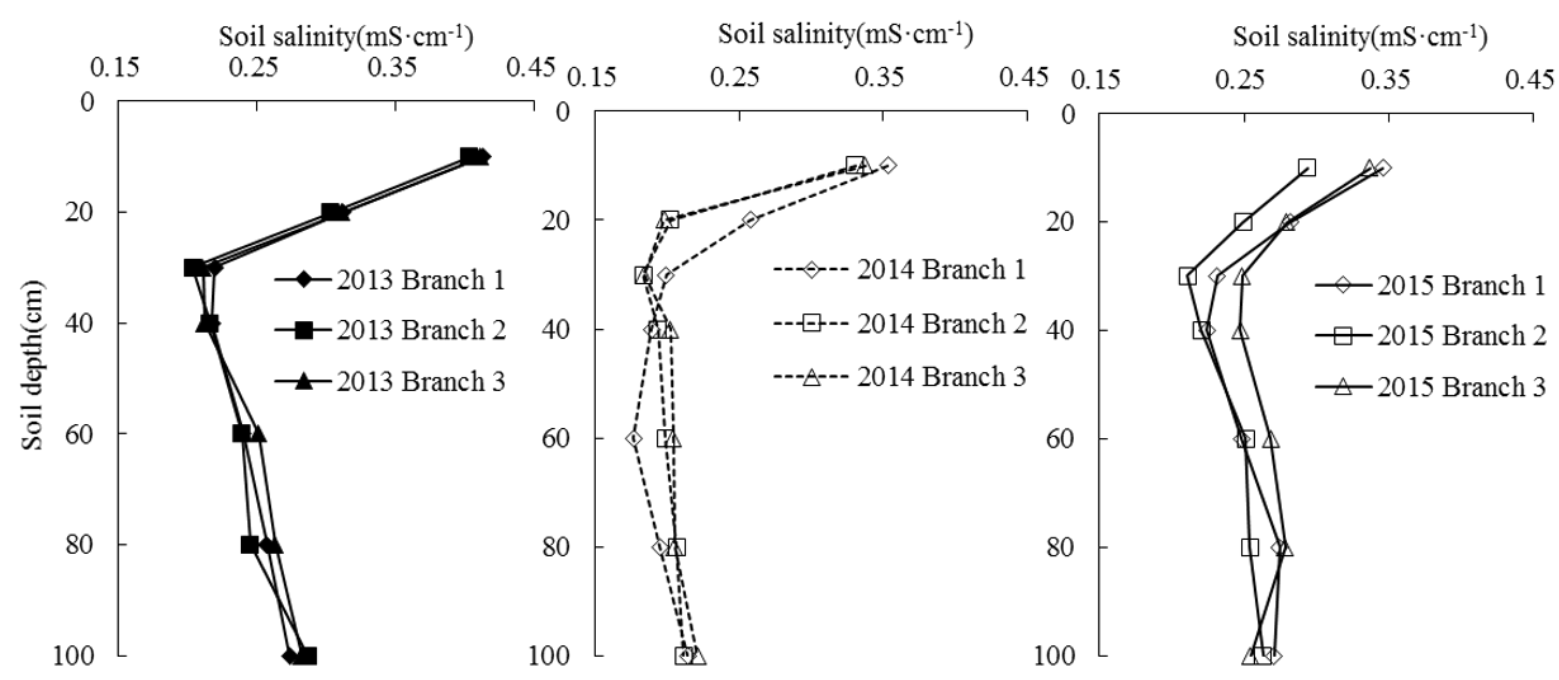

Figure 3. Soil salinity dynamics with soil depth in branch canal irrigation areas from 2013 to 2015.

In the irrigation areas of Branch 1, Branch 2, Branch 3, the ratio of surface water to groundwater irrigation ranged from 0.72-1.03, 2.50-2.63, 0.65-1.26 in 2013, 2014, and 2015, respectively (Table 2). The accumulation salinity for the top 100 $\mathrm{cm}$ horizons in Branch 2 irrigation area decreased slightly compared with the values in Branch 1, Branch 3 irrigation district by $1.63 \%$ to $8.90 \%$, which might be caused by salts in the surface water as well as a preponderance of downward water movement and subsequent leaching to subsoil and groundwater (Molle et al. 2010). The standard deviation of soil salinity calculated from 2013 to 2015 in the study area and the crops tolerances to salinity (Turkan et al. 2009) indicate that the accumulated salinity in the root soil layer will likely represent a serious problem as long as water allocation method increases the soluble salt input levels in the study area (Gao et al. 2015). In addition, compared with the concentration in 2014, the average TDS concentration of groundwater in 2015 increased by $18.66 \%$ in the study area. Under certain conditions, soil salinity may be significantly reduced after the irrigation because under the high rates of irrigation with surface water of low salinity, continual leaching of salts to lower horizons will occur (Daou et al. 2016). 
Teçnología y

Ciencias $\stackrel{\unlhd}{\unlhd}$ gua

Table 2. Salinity and salinity desalination rate in different soil layers.

\begin{tabular}{|c|c|c|c|c|c|c|c|c|}
\hline \multirow[b]{2}{*}{$\begin{array}{c}\text { Soil } \\
\text { Horizons } \\
(\mathrm{cm})\end{array}$} & \multirow[b]{2}{*}{$\begin{array}{l}\text { Irrigation } \\
\text { Area }\end{array}$} & \multicolumn{3}{|c|}{$2013-2014$} & \multicolumn{3}{|c|}{$2014-2015$} & \multirow{2}{*}{$\begin{array}{c}\text { Desalination } \\
\text { rate in } \\
2013-2015 \\
(\%)\end{array}$} \\
\hline & & $\begin{array}{c}\text { Initial soil } \\
\text { salinity } \\
\left(\mathrm{mS} \cdot \mathrm{cm}^{-1}\right)\end{array}$ & $\begin{array}{c}\text { Final soil } \\
\text { salinity } \\
\left(\mathrm{ms} \cdot \mathrm{cm}^{-1}\right)\end{array}$ & $\begin{array}{c}\text { Desalinati } \\
\text { on rate } \\
(\%)\end{array}$ & $\begin{array}{c}\text { Initial soil } \\
\text { salinity } \\
\left(\mathrm{mS} \cdot \mathrm{cm}^{-1}\right)\end{array}$ & $\begin{array}{l}\text { Final soil } \\
\text { salinity } \\
\left(\mathrm{mS} \cdot \mathrm{cm}^{-1}\right)\end{array}$ & $\begin{array}{l}\text { Desalination } \\
\text { rate (\%) }\end{array}$ & \\
\hline \multirow{3}{*}{$0-10$} & Branch 1 & 0.4129 & 0.3535 & 14.40 & 0.3535 & 0.3459 & 2.15 & 16.24 \\
\hline & Branch 2 & 0.4034 & 0.3308 & 17.99 & 0.3308 & 0.2938 & 11.20 & 27.18 \\
\hline & Branch 3 & 0.4111 & 0.3375 & 17.90 & 0.3375 & 0.3368 & 0.20 & 18.06 \\
\hline \multirow{3}{*}{$10-20$} & Branch 1 & 0.3114 & 0.2578 & 17.21 & 0.2578 & 0.2819 & -9.34 & 9.48 \\
\hline & Branch 2 & 0.3034 & 0.2024 & 33.28 & 0.2024 & 0.2494 & -23.21 & 17.80 \\
\hline & Branch 3 & 0.3111 & 0.1980 & 36.35 & 0.1980 & 0.2794 & -41.13 & 10.18 \\
\hline \multirow{3}{*}{$20-30$} & Branch 1 & 0.2194 & 0.1996 & 9.04 & 0.1996 & 0.2316 & -16.04 & -5.55 \\
\hline & Branch 2 & 0.2034 & 0.1835 & 9.78 & 0.1835 & 0.2107 & -14.81 & -3.59 \\
\hline & Branch 3 & 0.2111 & 0.1843 & 12.66 & 0.1843 & 0.2485 & -34.82 & -17.75 \\
\hline \multirow{3}{*}{$30-40$} & Branch 1 & 0.2178 & 0.1895 & 12.98 & 0.1895 & 0.2245 & -18.46 & -3.09 \\
\hline & Branch 2 & 0.2162 & 0.1938 & 10.33 & 0.1938 & 0.2206 & -13.80 & -2.05 \\
\hline & Branch 3 & 0.2122 & 0.2025 & 4.56 & 0.2025 & 0.2472 & -22.09 & -16.53 \\
\hline \multirow{3}{*}{$40-60$} & Branch 1 & 0.2399 & 0.1771 & 26.18 & 0.1771 & 0.2484 & -40.30 & -3.58 \\
\hline & Branch 2 & 0.2392 & 0.1989 & 16.83 & 0.1989 & 0.2513 & -26.33 & -5.07 \\
\hline & Branch 3 & 0.2512 & 0.2043 & 18.68 & 0.2043 & 0.2682 & -31.27 & -6.74 \\
\hline \multirow{3}{*}{$60-80$} & Branch 1 & 0.2569 & 0.1950 & 24.09 & 0.1950 & 0.2746 & -40.83 & -6.90 \\
\hline & Branch 2 & 0.2452 & 0.2070 & 15.57 & 0.2070 & 0.2542 & -22.80 & -3.67 \\
\hline & Branch 3 & 0.2633 & 0.2055 & 21.95 & 0.2055 & 0.2784 & -35.49 & -5.76 \\
\hline \multirow{3}{*}{$80-100$} & Branch 1 & 0.2737 & 0.2144 & 21.67 & 0.2144 & 0.2709 & -26.32 & 1.05 \\
\hline & Branch 2 & 0.2868 & 0.2117 & 26.20 & 0.2117 & 0.2629 & -24.19 & 8.34 \\
\hline & Branch 3 & 0.2819 & 0.2213 & 21.49 & 0.2213 & 0.2545 & -14.99 & 9.72 \\
\hline
\end{tabular}

\section{Spatial Dynamic of Soil Salinity with Irrigation Area}


The spatial dynamics of soil salinity in $20 \mathrm{~cm}$ profile in 2013 to 2015 are shown in Figure 4. The EC values averaged for the top $20 \mathrm{~cm}$ horizons in 2013, 2014, and 2015 were $0.3456,0.2820$ and $0.2991 \mathrm{mS} / \mathrm{cm}$ in the study area, respectively, whereas the standard deviations of the EC values were $0.071,0.058$ and 0.029 . For the whole examined soil profile $(0-20 \mathrm{~cm})$, the area of EC value exceeded $0.32 \mathrm{mS} / \mathrm{cm}$ (equal to $1.50 \mathrm{~g} / \mathrm{kg}$ soil salinity) was calculated by Sufer 13.0 (Golden Software, LLC ), 60.38\%, 59.61\% and $84.40 \%$ were presented respectively from Branch 1, Branch 2 and Branch 3 irrigation area in 2013. To $2014,25.99 \%, 0.94 \%$ and $41.87 \%$ were presented respectively from the above mentioned irrigation area, in comparison with 2013, the area of EC value exceeded $0.32 \mathrm{mS} / \mathrm{cm}$ from Branch 1, Branch 2 and Branch 3 irrigation district has been decreased by $56.95 \%, 98.42 \%$ and $50.39 \%$, respectively. In addition, $41.16 \%, 8.81 \%$ and $52.49 \%$ were obtained respectively from above mentioned irrigation area, in comparison with 2013, the area of EC value exceeded 0.32 $\mathrm{mS} / \mathrm{cm}$ from above mentioned irrigation district has been decreased by $31.83 \%$, $85.22 \%$ and $37.81 \%$, respectively.

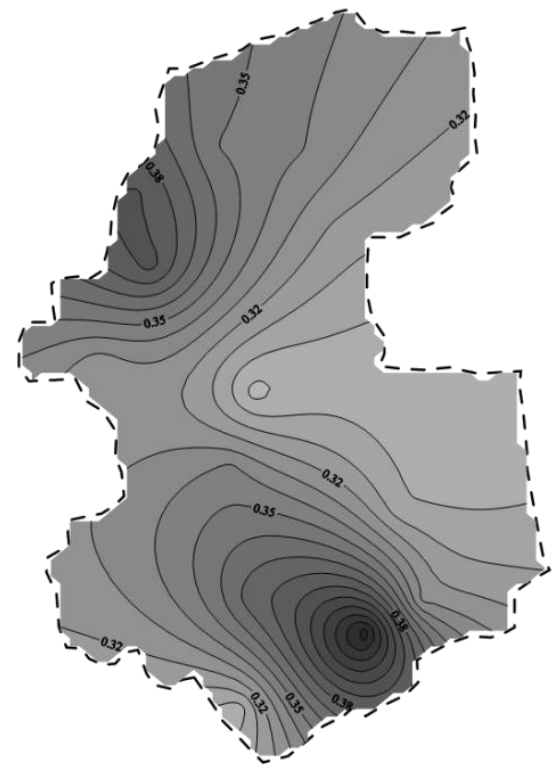

2013

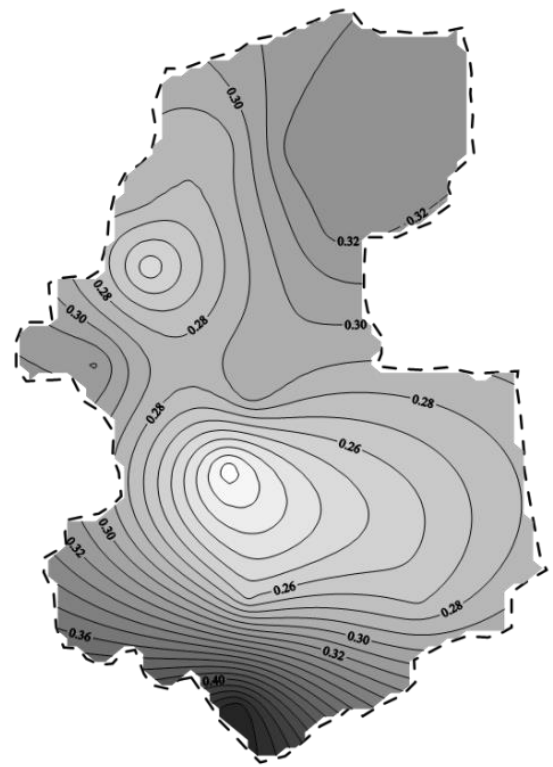

2014

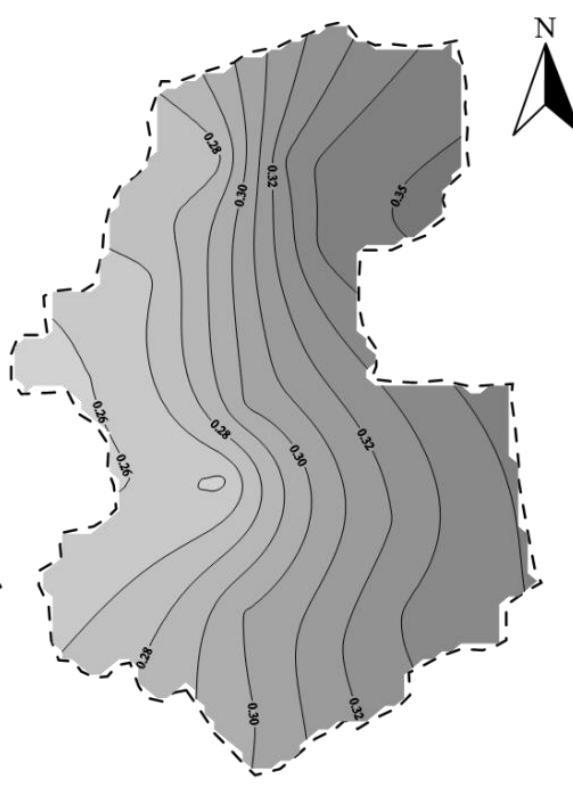

2015

0

12

$3 \mathrm{~km}$

Figure 4. Distribution of average soil salinity of 0 to $20 \mathrm{~cm}$ soil layer in research areas from 2013 to 2015.

Compared with the area in the hydrological period in 2013, the area of average soil salinity exceeded $0.32 \mathrm{mS} / \mathrm{cm}$ for the top $20 \mathrm{~cm}$ horizons decreased notably 
due to low salt precipitation leaching caused by the high rate of medium concentration water employed for irrigation in the study area (Li et al. 2016). In the present study, the area of average soil salinity exceeded $0.32 \mathrm{mS} / \mathrm{cm}$ for the top $20 \mathrm{~cm}$ horizons was a negative relationship with canal well water ratio, that is, on top $20 \mathrm{~cm}$ layers, average soil salinity content in higher CWWR irrigation area was lower as compared to content in soil from lower CWWR irrigation area (Ghazaryan et al. 2016). The results for the soil desalination rate for the top 100 $\mathrm{cm}$ horizons showed that areas with higher CWWRs presented increased values at all sampled depths of the profile and the EC values declined with increasing CWWRs because under the high CWWRs, continual leaching of salts to lower layers occurs. In addition, irrigation with low-salt water caused a drop in the root layer salinity. No doubt, surface water application caused an appreciated decrease in soil salinity, which may eliminate the risk of crop salt stress (Dai et al. 2015).

\section{Effect of Soil Profile Desalination with Branch Canal Irrigation Area}

The results from soil horizon desalination calculations of the branch canal irrigation area showed that irrigation by the water allocation patterns caused increases in salinity levels in the lower layer $(20-80 \mathrm{~cm})$, and decreased in salinity levels in the top layer $(0-20 \mathrm{~cm})$. It was observed that average EC value at all sampled depths of the profile in 2014 was lower than that of 2013 , by $9.04 \%$ to $36.35 \%$, while average EC value at examined soil profile $(0-10,10-20$ and $80-100 \mathrm{~cm}$ ) in 2015 was lower than that of 2013 , by $1.05 \%$ to $27.18 \%$. Additionally, compared with Branch 1, Branch 3 irrigation district, soil desalination rate for top $20 \mathrm{~cm}$ horizons in 2013 to 2015 in Branch 2 was 23.15\%, increased by $73.65 \%, 57.86 \%$, respectively. Furthermore, in comparison with 2013, average EC values for 20-30, 30-40, 40-60 and 60-80 cm layer in 2015 has slightly accumulated, meaningfully, for the examined soil profiles $(20-80 \mathrm{~cm})$, soil desalination in the Branch 2 irrigation area was $-5.78 \%$, which was higher than that in the Branch 1, Branch 3 irrigation area by $21.84 \%$ and $60.99 \%$, respectively.

\section{Effect of Groundwater Hydro-Chemical Characteristics with}




\section{Branch Canal Irrigation Area}

The hydro-chemical characteristics of examined groundwater in Branch 1, Branch 2, Branch 3 irrigation areas are shown in table 3. The water types are generally distinct zones in which the cation and anion concentrations are described within the defined composition categories, and the dominant anion species of water changes systematically from $\mathrm{HCO}_{3}{ }^{-}, \mathrm{Cl}^{-}$to $\mathrm{SO}_{4}{ }^{2-}$ along groundwater flow direction from the irrigation area (Wang et al. 2014, Reddy et al. 2012). The Piper diagram (Wen et al. 2005) in Figure 5 shows that the water type in above-mentioned irrigation areas had similar change trends as groundwater. That is, during the dry period (December, January and February), normal period (March, April, May, October and November), wet period (June, July, August and September), the cation types were $\mathrm{Ca}^{2+} / \mathrm{Na}^{+}, \mathrm{Na}^{+} / \mathrm{Ca}^{2+}, \mathrm{Ca}^{2+} / \mathrm{Na}^{+}$, respectively. This result indicates that groundwater type had an obvious alkaline trend because of cation change of $\mathrm{Ca}^{2+} / \mathrm{Na}^{+}$in the dry period to $\mathrm{Na}^{+} / \mathrm{Ca}^{2+}$ in the normal period. Under certain conditions, groundwater hydro-chemical characteristics may be significantly impacted during winter wheat growth stage because under the high rates of phreatic evapotranspiration with unsuitable water allocation there would concentrate groundwater TDS (Rozema et al. 2008, Karmegam et al. 2011, Brunner et al. 2008). Additionally, in comparison with the dry period in 2014, average TDS concentrations of groundwater in 2015 were increased by $30.28 \%, 21.83 \%, 33.95 \%$ in Branch 1, Branch 2, Branch 3 irrigation area, respectively. While the normal period in 2014, average TDS concentrations of groundwater in 2015 were increased by $13.35 \%, 27.88 \%$, $5.17 \%$, and wet period, the increasing values of TDS in 2015 was $0.81 \%, 18.29 \%$ and $16.43 \%$ in the above mentioned area, respectively. It was observed that compared with 2014, average TDS concentration has been increased by 1.28 , $1.15,1.12$ fold in the dry period, normal period and wet period with study area. From normal period groundwater with Branch 2 irrigation area, in comparison with Branch 1 and Branch 3 irrigation area, value added of TDS was improved by $1.23,3.48$ fold, respectively. No doubt, water allocation employed in the study area caused appreciable increased TDS in groundwater, which may improve the risk of groundwater irrigation occurring normal period.

Table 3. Annual dynamics of groundwater hydrochemical characteristics of a typical branch canal irrigation area.

\begin{tabular}{|c|c|c|c|c|c|c|c|c|c|c|c|}
\hline Year Irrigation & Water & $\mathrm{Ca}^{2+}$ & $\mathrm{Mg}^{2+}$ & $\mathrm{Na}^{+}$ & $\mathrm{K}^{+}$ & $\mathrm{CO}_{3}{ }^{2-}$ & $\mathrm{HCO}_{3}{ }^{-}$ & $\mathrm{Cl}^{-}$ & $\mathrm{SO}_{4}{ }^{2-}$ & TDS & SAR \\
\hline
\end{tabular}


Teçnología y

Ciencias $\stackrel{\varpi}{\varpi}$ gua
2019, Instituto Mexicano de Tecnología del Agua

Open Access, license CC BY-NC-SA 4.0

(https://creativecommons.org/licenses/by-nc-sa/4.0/)

\begin{tabular}{|c|c|c|c|c|c|c|c|c|c|c|c|c|}
\hline & Area & period & $\left(\mathrm{mg} \cdot \mathrm{L}^{-1}\right)$ & $\left(\mathrm{mg} \cdot \mathrm{L}^{-1}\right)$ & $\left(\mathrm{mg} \cdot \mathrm{L}^{-1}\right)$ & $\left(\mathrm{mg} \cdot \mathrm{L}^{-1}\right.$ & $\left(\mathrm{mg} \cdot \mathrm{L}^{-1}\right.$ & $\left(\mathrm{mg} \cdot \mathrm{L}^{-1}\right)$ & $\left(\mathrm{mg} \cdot \mathrm{L}^{-1}\right)$ & $\left(\mathrm{mg} \cdot \mathrm{L}^{-1}\right)$ & $\left(\mathrm{mg} \cdot \mathrm{L}^{-1}\right)$ & \\
\hline \multirow{9}{*}{2014} & \multirow{3}{*}{ Branch 1} & $\begin{array}{c}\text { Dry } \\
\text { period }\end{array}$ & 112.88 & 11.67 & 129.25 & 0.00 & 0.00 & 403.72 & 126.37 & 131.80 & 895.63 & 16.38 \\
\hline & & $\begin{array}{c}\text { Normal } \\
\text { period }\end{array}$ & 83.56 & 23.38 & 167.18 & 0.00 & 0.00 & 412.91 & 126.38 & 156.55 & 947.41 & 22.86 \\
\hline & & $\begin{array}{c}\text { Wet } \\
\text { period }\end{array}$ & 187.18 & 43.96 & 194.63 & 0.00 & 0.00 & 485.28 & 126.38 & 145.93 & 868.49 & 18.10 \\
\hline & \multirow{3}{*}{ Branch 2} & $\begin{array}{c}\text { Dry } \\
\text { period }\end{array}$ & 140.40 & 28.70 & 167.70 & 0.00 & 0.00 & 555.78 & 136.18 & 178.53 & 1113.43 & 18.24 \\
\hline & & $\begin{array}{c}\text { Normal } \\
\text { period }\end{array}$ & 82.93 & 39.98 & 201.12 & 0.00 & 0.00 & 511.53 & 126.33 & 186.85 & 1009.83 & 25.66 \\
\hline & & $\begin{array}{c}\text { Wet } \\
\text { period }\end{array}$ & 212.19 & 58.14 & 230.06 & 0.00 & 0.00 & 576.53 & 142.73 & 205.05 & 838.24 & 19.79 \\
\hline & \multirow{3}{*}{ Branch 3} & $\begin{array}{c}\text { Dry } \\
\text { period }\end{array}$ & 91.20 & 32.30 & 162.00 & 0.00 & 0.00 & 373.30 & 135.10 & 188.10 & 981.20 & 20.62 \\
\hline & & $\begin{array}{c}\text { Normal } \\
\text { period }\end{array}$ & 101.87 & 45.17 & 259.13 & 0.00 & 0.00 & 519.83 & 165.57 & 330.20 & 1214.30 & 30.22 \\
\hline & & $\begin{array}{c}\text { Wet } \\
\text { period }\end{array}$ & 222.68 & 75.13 & 233.50 & 0.00 & 0.00 & 647.05 & 174.33 & 234.73 & 814.67 & 19.14 \\
\hline \multirow{8}{*}{2015} & \multirow{3}{*}{ Branch 1} & $\begin{array}{c}\text { Dry } \\
\text { period }\end{array}$ & 130.86 & 18.71 & 149.25 & 0.00 & 0.00 & 488.97 & 133.55 & 209.33 & 1166.82 & 21.44 \\
\hline & & $\begin{array}{c}\text { Normal } \\
\text { period }\end{array}$ & 111.35 & 34.58 & 185.41 & 0.00 & 0.00 & 496.35 & 119.46 & 162.86 & 1073.85 & 17.47 \\
\hline & & $\begin{array}{c}\text { Wet } \\
\text { period }\end{array}$ & 234.12 & 33.74 & 182.68 & 0.00 & 0.00 & 371.11 & 140.07 & 112.28 & 875.51 & 15.79 \\
\hline & \multirow{3}{*}{ Branch 2} & $\begin{array}{c}\text { Dry } \\
\text { period }\end{array}$ & 135.42 & 28.47 & 157.24 & 0.00 & 0.00 & 609.87 & 151.12 & 211.70 & 1356.47 & 24.29 \\
\hline & & $\begin{array}{c}\text { Normal } \\
\text { period }\end{array}$ & 138.31 & 49.90 & 219.89 & 0.00 & 0.00 & 630.44 & 128.03 & 187.46 & 1291.38 & 16.21 \\
\hline & & $\begin{array}{c}\text { Wet } \\
\text { period }\end{array}$ & 233.45 & 41.55 & 208.41 & 0.00 & 0.00 & 416.89 & 166.13 & 123.40 & 991.53 & 17.77 \\
\hline & \multirow{2}{*}{ Branch 3} & $\begin{array}{c}\text { Dry } \\
\text { period }\end{array}$ & 144.00 & 32.52 & 143.09 & 0.00 & 0.00 & 564.11 & 156.13 & 223.53 & 1314.34 & 20.66 \\
\hline & & $\begin{array}{c}\text { Normal } \\
\text { period }\end{array}$ & 166.28 & 39.88 & 194.06 & 0.00 & 0.00 & 642.88 & 177.58 & 187.43 & 1277.11 & 14.09 \\
\hline
\end{tabular}




\begin{tabular}{|l|l|c|c|c|c|c|c|c|c|c|c|}
\hline & $\begin{array}{c}\text { Wet } \\
\text { period }\end{array}$ & 239.48 & 48.45 & 207.63 & 0.00 & 0.00 & 456.63 & 178.60 & 117.13 & 948.48 & 17.30 \\
\hline
\end{tabular}
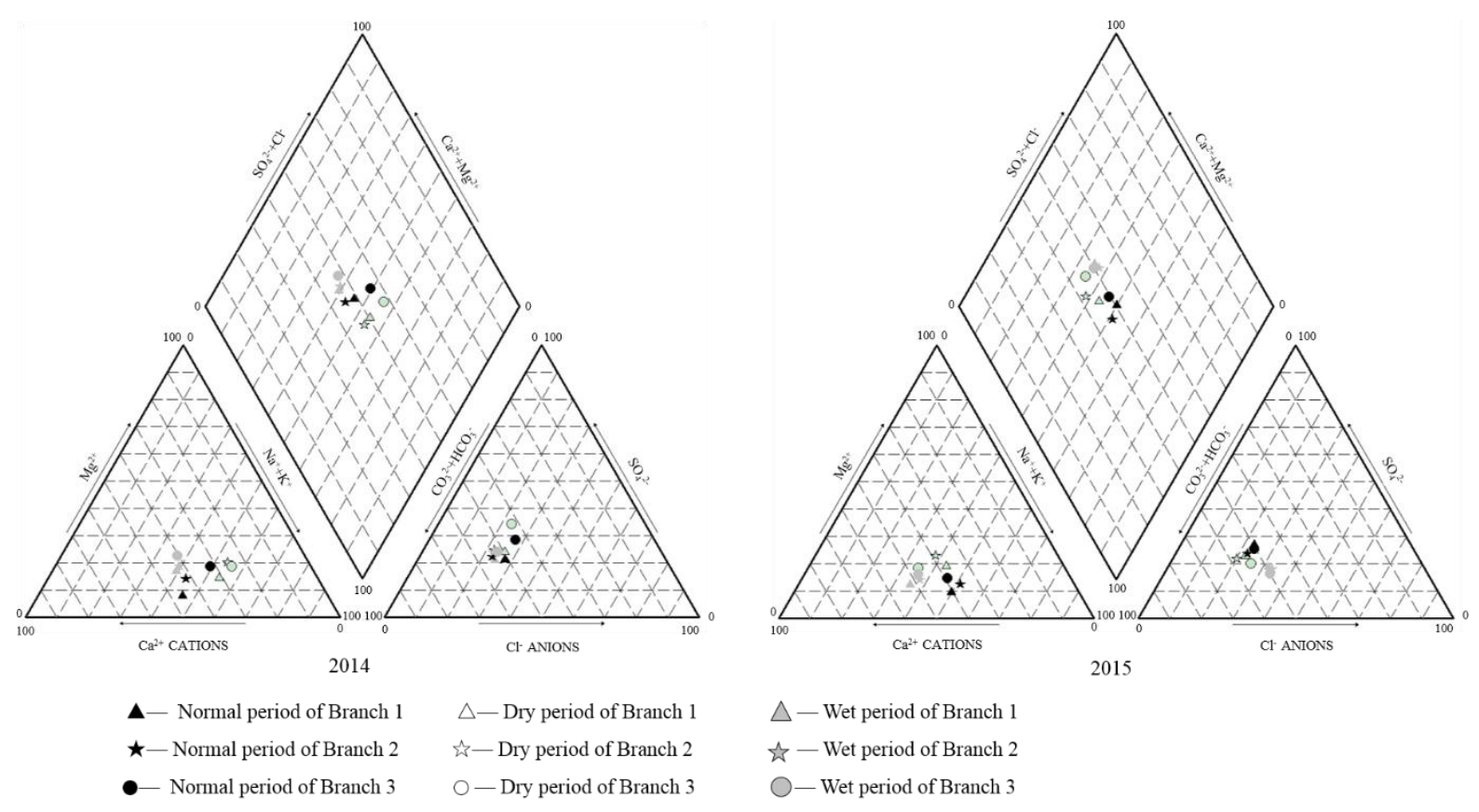

Figure 5. Dynamics of groundwater hydrochemistry of typical areas under CWWs from 2013 to 2015.

In comparison with that in the hydrological period in 2014, the average groundwater TDS concentration in 2015 was increased by $22.67 \%$ in the study area, which might be due to groundwater exploration as well as a preponderance of phreatic evaporation and subsequent irrigation leaching (Rao et al. 2008). In the present study, SARs of groundwater from Branch 1, Branch 2, Branch 3 irrigation area in the normal period were greater than 18. According to the agricultural irrigation water alkalization classification standard (Li et al. 2013, Vasanthavigar et al. 2010), if SAR values of groundwater were exceeded 18, then it is not fit for irrigation. Additionally, compared with the values in 2014 , the SAR values in the above-mentioned irrigation area decreased by $23.58 \%, 36.82 \%$, $53.37 \%$ in normal period, respectively. Furthermore, the SAR values in the above mentioned irrigation area were less than 18 in 2015. The groundwater SAR dynamics occurred largely as a result of the input of ions by surface irrigation, the leaching of ions by precipitation, or the evaporation of ions from groundwater. The decrease of groundwater SAR values in 2015 may have increased agricultural water resources and ensured the positive effect of water allocation (Chaudhuri et al. 2014, Huang et al. 2013). 


\section{Conclusions}

Larger CWWRs modify the accumulation of salinity in topsoil. Additionally, in comparison with areas exceeded $0.32 \mathrm{mS} / \mathrm{cm}$ in $0-20 \mathrm{~cm}$ soil profile in a lower ratio of canal well water irrigation district, the results showed that canal water irrigation caused decreased soil salinity to the depths of $20 \mathrm{~cm}$ in the study area. Compared with rates in the hydrological period in 2013, soil desalination rate to the depths of $20 \mathrm{~cm}$ in 2014 and 2015 was notably increased, and the rates improved with the CWWR. For soil desalination to the depths of $100 \mathrm{~cm}$ from 2013 to 2015, larger CWWRs promoted salinity leaching to lower soil profiles and groundwater. Thus, water allocation employed in the study area might increase groundwater TDS concentration, which can result in alkalization trend of cation types in the normal period. A decrease in the sodium adsorption ratio was observed in the normal and wet period in 2015 compared with the value in 2014 because of irrigation water recharge to groundwater caused by water with low TDS concentrations employed for irrigation in the study area. However, possible increases of TDS in the groundwater may cause potential risks after long term water allocation in the study area. Therefore, water allocation should be emphasized to maintain a healthy groundwater environment and sustainable stable yields of grain in combined canal-well irrigation areas.

\section{Acknowledgments}

The research was financially supported by the Chinese Academy of Agricultural Sciences Basal Scientific Research Fund (FIRI2017-10) and the Agricultural Science and Technology Innovation Program of Chinese Academy of Agricultural Sciences (CAAS-ASTIP-FIRI-03).

\section{References}

Rozema, J. \& Flowers, T. (2008). Crops for a salinized world. Science, 322: 14781480.

Yang, B., Zhang, Y. C., Qian, Y., Tang, J. \& Liu, D. Q. (2016). Climatic effects of irrigation over the Huang-Huai-Hai Plain in China simulated by the weather research and forecasting model. Journal of Geophysical Research-Atmospheres, 121: 2246-2264. 
Shi, W. J., Tao, F. L. \& Liu, J. Y. (2013). Changes in quantity and quality of cropland and the implications for grain production in the Huang-Huai-Hai Plain of China. Food Security, 5, 69-82.

Wei, Y. Q. (1995). Soil salinization present and future from water and salt balance of Huang-Huai-Hai Plain. Progress in Soil Sciences, 23(2), 18-25. (in Chinese).

Yang, X. L., Gao, W. S., Shi, Q. H., Chen, F. \& Chu, Q. Q. (2013). Impact of climate change on the water requirement of summer maize in the Huang-Huai-Hai farming region. Agricultural Water Management, 124, 20-27.

Yang, J. Y., Mei, X. R., Huo, Z. G., Yan, C. R., Ju, H., Zhao, F. H. \& Liu, Q. (2015). Water consumption in summer maize and winter wheat cropping system based on SEBAL model in Huang-Huai-Hai Plain, China. Journal of Integrative Agriculture, 14, 2065-2076.

Li, P., Magzum, N., Liang, Z. J., Huang, Z. D. \& Qi, X. B. (2017). Effects of canal well water ratios on root layer soil desalination and groundwater hydrochemical characteristics. Scientia Agricultura Sinica, 50(3), 526-536. (in Chinese).

Han, D. R., Sun, Z. G., Li, F. D., Hou, R. X., Li, J., Ouyang, Z., Li, B. B. \& Cao, C. W. (2016). Changes and controlling factors of cropland soil organic carbon in North China Plain over a 30-year period. Plant and Soil, 403, 437-453.

Mora, J. L., Herrero, J. \& Weindorf, D. C. (2017). Multivariate analysis of soil salination-desalination in a semi-arid irrigated district of Spain. Geoderma, 291, $1-10$.

Wang, J. H., Hou, B. D., Jiang, D. C., Xiao, W. H., Wu, Y. X., Zhao, Y., Zhou, Y. Y., Guo, C. S. \& Wang, G. X. (2016). Optimal Allocation of Water Resources Based on Water Supply Security. Water, 8, 237.

Fulazzaky, M. A. (2014). Challenges of Integrated Water Resources Management in Indonesia. Water, 6, 2000-2020.

Bekchanov, M., Karimov, A. \& Lamers, J. P. A. (2010). Impact of Water Availability on Land and Water Productivity: A Temporal and Spatial Analysis of the Case Study Region Khorezm, Uzbekistan. Water, 2, 668-684.

Sadati, S. K., Speelman, S., Sabouhi, M., Gitizadeh, M. \& Ghahraman, B. (2014). Optimal Irrigation Water Allocation Using a Genetic Algorithm under Various Weather Conditions. Water, 6, 3068-3084.

Wu, X., Zheng, Y., Wu, B., Tian, Y., Han, F. \& Zheng, C. (2016). Optimizing conjunctive use of surface water and groundwater for irrigation to address human-nature water conflicts: A surrogate modeling approach. Agricultural Water Management, 163, 380-392.

Parna, P., Armaghan, A. \& Reza, K. (2015). A heuristic evolutionary game theoretic methodology for conjunctive use of surface and groundwater resources. Water Resources Management, 29, 3905-3918. 
Esmaeili, A. \& Shahsavari, Z. (2015). Water allocation for agriculture in southwestern Iran using a programming model. Appl. Water Sci.5, 305-310.

Al-Omari, A., Al-Quraan, S., Al-Salihi, A. \& Abdulla, F. (2009). A Water Management Support System for Amman Zarqa Basin in Jordan. Water Resour. Manage, 23, 3165-3189.

Mo, X., Wu, J. J., Wang, Q. \& Zhou, H. (2016). Variations in water storage in China over recent decades from GRACE observations and GLDAS. Natural Hazards and Earth System Sciences, 16, 469-482.

Singh, A., Panda, S.N., Flugel, W.A. \& Krause, P. (2012). Waterlogging and farmland salinization: causes and remedial measures in an irrigated semi-arid region of India. Irrigation and Drainage, 61, 357-365.

Molden, D., De Fraiture, C. \& Rijsberman, F. (2007). Water scarcity - The food factor. Issues in Science and Technology, 23, 39-48.

Molle, F., Wester, P. \& Hirsch, P. (2010). River basin closure: Processes, implications and responses. Agricultural Water Management, 97, 569-577.

Wang, H. J., Shi, J. C., Zhang, H. L., Sheng, J. D. \& Ma, X. W. (2014). Soil salinity dynamic change and desalting effect under different improvement measures in severe salinity soil in Xinjiang. Transactions of the Chinese Society of Agricultural Engineering, 30, 102-111. (in Chinese).

Reddy, A. G. S., Saibaba, B. \& Sudarshan, G. (2012). Hydrogeochemical characterization of contaminated groundwater in Patancheru Industrial Area, Southern India. Environ. Monit. Assess, 184, 3557-3576.

Wen X., Wu Y., Su J., Zhang Y. \& Liu F. (2005). Hydrochemical Characteristics and Salinity of Groundwater in the Ejina Basin, Northwestern China. Environ. Geol. 48, 665-675.

Karmegam, U., Chidambaram, S., Prasanna, M. V., Sasidhar, P., Manikandan, S., Johnsonbabu, G., Dheivanayaki, V., Paramaguru, P., Manivannan, R., Srinivasamoorthy, K. \& Anandhan, P. (2011). A study on the mixing proportion in groundwater samples by using piper diagram and phreeqc model. Chin. J. Geochem.30, 490-495.

Brunner, P., Li, H. T., Kinzelbach, W., Li, W. P. \& Dong, X. G. (2008). Extracting phreatic evaporation from remotely sensed maps of evapotranspiration. Water Resources Research, 44, w08428.

Turkan, I. \& Demiral, T. (2009). Recent developments in understanding salinity tolerance. Environmental and Experimental Botany, 67, 2-9.

Gao, X. Y., Huo, Z. L., Bai, Y. N., Feng, S. Y., Huang, G. H., Shi, H. B. \& Qu, Z. Y. (2015). Soil salt and groundwater change in flood irrigation field and uncultivated land: a case study based on 4-year field observations. Environmental Earth Sciences, 73, 2127-2139. 
Daou, C., Nabbout, R. \& Kassouf, A. (2016). Spatial and temporal assessment of surface water quality in the Arka River, Akkar, Lebanon. Environmental Monitoring and Assessment, 188, 684.

Li, P., Qi, X.B., Magzum, N., Huang, Z.D., Liang, Z.J. \& Qiao, D.M. (2016). Effect of Water Resources Allocation on Groundwater Environment and Soil Salinity Accumulation under Climate Change. Journal of Earth Science and Engineering, 6, 73-82.

Ghazaryan, K. \& Chen, Y. N. (2016). Hydrochemical assessment of surface water for irrigation purposes and its influence on soil salinity in Tikanlik oasis, China. Environmental Earth Sciences, 75, 383.

Dai, Y., Senge, M., Ito, K., Onishi, T. \& Yoshiyam, K. (2015). Experimental evaluation of irrigation methods for soil desalinization. Paddy and Water Environment, 13, 159-165.

Rao, N.S. (2008). Factors controlling the salinity in groundwater in parts of Guntur district, Andhra Pradesh, India. Environmental Monitoring and Assessment, 138, 327-341.

Li, P. Y., Wu, J. H. \& Qian, H. (2013). Assessment of groundwater quality for irrigation purposes and identification of hydrogeochemical evolution mechanisms in Pengyang County, China. Environmental Earth Sciences, 69, 2211-2225.

Vasanthavigar, M., Srinivasamoorthy, K., Vijayaragavan, K., Ganthi, R. R., Chidambaram, S., Anandhan, P., Manivannan, R. \& Vasudevan, S. (2010). Application of water quality index for groundwater quality assessment: Thirumanimuttar sub-basin, Tamilnadu, India. Environmental Monitoring and Assessment, 171, 595-609.

Chaudhuri, S. \& Ale, S. (2014). Long term (1960-2010) trends in groundwater contamination and salinization in the Ogallala aquifer in Texas. Journal of Hydrology, 513, 376-390.

Huang, T. M., Pang, Z. H., Chen, Y. N. \& Kong, Y. L. (2013). Groundwater circulation relative to water quality and vegetation in an arid transitional zone linking oasis, desert and river. Chinese Science Bulletin, 58, 3088-3097. 